\title{
JACEK (HIACYNT) BORATYŃSKI - PODCZASZY ŻYDACZOWSKI I PORUCZNIK HUSARSKI W DOBIE WOJEN POLSKO-TURECKICH W DRUGIEJ POLOWIE XVII WIEKU. STUDIUM Z ZAWODU ŻOLNIERSKIEGO
}

Biografistyka wojskowa poświęcona oficerom średniego i niższego szczebla dowodzenia, którzy działali w drugiej połowie XVII w., w ostatnich latach cieszy się szerokim zainteresowaniem, przybywa bowiem dużych monografii dotyczących poszczególnych środowisk kadry dowódczej w armii koronnej, jak również ujęć leksykalnych oraz artykułów biograficznych. Stan prac z tego zakresu został niedawno omówiony w artykule na temat przebiegu służby wojskowej w latach I656-I706 wojewody podolskiego Nikodema Żaboklickiego', co zwalnia mnie w tym miejscu z przedstawiania dotychczasowych osiągnięć polskiej historiografii w dziedzinie biografistyki wojskowej i prozopografii poświęconej drugiej połowie wieku XVII. Niniejsze rozważania wpisywać się będą w gatunek artykułów biograficznych omawiających przebieg służby wojskowej poruczników husarskich. Z tego typu tekstów warto wymienić te, które przedstawiły kolejne losy dowódców jazdy kopijniczej takich jak Aleksander Polanowski, Zygmunt Zbierzchowski, wspominany wyżej Nikodem Żaboklicki czy Władysław Wilczkowski ${ }^{2}$. Byli to jednak oficerowie dobrze rozpoznawani w ówczesnym społeczeństwie, którzy dzięki swej wieloletniej żołnierskiej służbie zanotowali wyraźny awans społeczny, urzędniczy oraz materialny, nie mówiąc o samych karierach wojskowych. Zupełnie inny jest przykład Jacka Boratyńskiego, który pozostaje znany jedynie specjalistom od wojskowości staropolskiej doby panowania Jana III Sobieskiego. Boratyński nie zanotował oszałamiających sukcesów, które pozwoliłyby mu zostać szerzej zapamiętanym przez historię, ale jako typowy przedstawiciel swojej grupy zawodowej cechował się profesjonalizmem, co skutkowało zaufaniem do niego dwóch kolejnych patronów chorągwi husarskiej, w której przyszło mu dowodzić. Niewątpliwie dlatego warto poświęcić temu dowódcy osobne rozważania, przy uwzględnieniu, że umożliwia to zachowana baza źródłowa, a życiorys interesującej mnie postaci został omówiony jedynie w haśle słownikowym, przygotowanym przez Marka Wagnera, oraz w pewnym stopniu w pracy o husarii koronnej z czasów wojny

\footnotetext{
Z. Hundert, J.J. Sowa, Od towarzysza jazdy do wojewody podolskiego. Przebieg służby wojskowej Nikodema Żaboklickiego w latach 1656-1706, „Res Historica”, 42/2016, s. 127-181.

2 Z. Hundert, Władysław Wilczkowski, porucznik husarski i pułkownik królewski, w: Na z góry upatrzonych pozycjach, red. B. Międzybrodzki et al., Warszawa-Zabrze 2011, s. 165-173; idem, Aleksander Polanowski-porucznik husarski oraz pułkownik Jego Królewskiej Miłości, „Studia z Dziejów Wojskowości”, 2/2013, s. 41-70; M. Wagner, Zapomniany bohater bitwy wiedeńskiej. Zygmunt Zbierzchowski (około 1635-1691) - porucznik husarski, w: Do szarży marsz, marsz... Studia z dziejów kawalerii, red. A. Smoliński, t. 4, Toruń 2013, s. 63-86.
} 
polsko-tureckiej z lat I672-16763. Zgodnie jednak z obecnym stanem wiedzy dotychczasowe ustalenia na temat Boratyńskiego wymagają wyraźnych uzupełnień, a czasem weryfikacji. Temu służy niniejszy artykuł.

Jacek Boratyński herbu Topór, który występuje w źródłach również z łacińską wersją imienia - Hiacynt, wywodził się z rodziny piszącej się z Boratynia w ziemi przemyskiej województwa ruskiego. Był synem Samuela i wnukiem Jana Mikołaja, który już w I607 r. tytułował się starostą lipnickim, tj. posiadał tenutę w ziemi dobrzyńskiej. Jan Mikołaj, zmarły przed 1627 r.5, mógł niewątpliwie stanowić wzór dla Jacka - w trakcie kampanii chocimskiej I62I r. stał bowiem na czele pułku kawalerii w sile ok. I00o koni. Zgrupowanie jazdy Boratyńskiego składało się z czterech chorągwi husarskich i trzech kozackich, wśród których znajdowała się I50-konna rota husarska pułkownika ${ }^{6}$. W ten sposób Jacek mógł odwoływać się do oficerskich i husarskich tradycji swojej rodziny, wyrażonych w służbie wojskowej dziadka Jana Mikołaja. Obecnie nie dysponujemy wiedzą, kiedy przyszły podczaszy żydaczowski się urodził, kto był jego matką i czy miał rodzeństwo. Jeżeli chodzi o pierwszy aspekt, to jeśli przyjmiemy, że służbę wojskową rozpoczął w latach sześćdziesiątych XVII w., co sugerują rejestry popisowe jednej chorągwi (o czym niżej), to prawdopodobnie na świat przyszedł w latach czterdziestych. Możemy przy tym dodać, że nie pochodził z rodziny, która w XVII w. odgrywała większą rolę w województwie ruskim, sam Jacek był bowiem pierwszym przedstawicielem Boratyńskich herbu Topór pełniącym w latach „srebrnego wieku" urzędy ziemskie na obszarze Rusi Czerwonej

Początek służby wojskowej Boratyńskiego jest trudny do ustalenia. Pierwszym przydziałem służbowym późniejszego podczaszego żydaczowskiego mogła być chorągiew husarska koniuszego koronnego Aleksandra Michała Lubomirskiego. Nazwisko Boratyńskiego w poczcie trzykonnym pojawia się bowiem w wykazach tej jednostki w kwartale służby liczonym od I sierpnia I666 r. Zachowane rejestry roty Lubomirskiego (od I668 r. wojewody krakowskiego), dowodzonej przez starostę wiszeńskiego i zwinogrodzkiego Władysława Wilczkowskiego, strukturalnie należącej do pułku królewskiego Jana Kazimie$\mathrm{rza}^{8}$, wymieniają nazwisko Boratyńskiego na czele trzykonnego pocztu do końca drugiego

\footnotetext{
3 M. Wagner, Stownik biograficzny oficerów polskich drugiej połowy XVII wieku, t. 1, Oświęcim 2013, s. 30, hasło: Boratyński Jacek; Z. Hundert, Husaria koronna w wojnie polsko-tureckiej 1672-1676, wyd. 2, Oświęcim 2014, s. 216, 250-251 i in.; por. idem, Choragiew husarska Jana Sobieskiego w latach 1673-1676. Aspekty organizacyjne, społeczne i finansowe, w: Spes in virtute, salus in victoria: Materiaty z „IX Ogólnopolskiej Konferencji Studentów Historyków Wojskowości", Lublin 8-10 grudnia 2011, red. A. Gładysz et al., Lublin-Zabrze 2013, s. 131.

4 A. Boniecki, Herbarz Polski, t. 2, Warszawa 1900, s. 21; M. Wagner, Stownik biograficzny ..., s. 30, hasło: Boratyński Jacek.

5 A. Boniecki, op. cit., s. 21.

${ }^{6}$ Komput chocimski 1621 z rękopisu Biblioteki Narodowej, oprac. Z. Hundert, K. Żojdź, w: Studia nad staropolska sztuka wojenna, t. 2, red. Z. Hundert, Oświęcim 2013, s. 250.

7 Zob. Urzędnicy dawnej Rzeczypospolitej XII-XVIII wieku, red. A. Gąsiorowski, t. 3, z. 1: Urzędnicy województwa ruskiego XIV-XVIII wieku, (dalej: Urzędnicy województwa ruskiego), oprac. K. Przyboś, Wrocław-Warszawa-Kraków-Gdańsk-Łódź 1987, s. 311 (indeks).

8 Przydział chorągwi Lubomirskiego do pułku królewskiego w latach 1663-1667 potwierdzają rachunki sejmowe z lat 1668 i 1672, ukazujące rozliczenia trybunałów skarbowych z lat 1667 i 1671 z wojskiem; zob. rachunki sejmowe 1668 i 1672, Archiwum Główne Akt Dawnych w Warszawie (dalej: AGAD), Archiwum Skarbu Koronnego (dalej: ASK), dz. II, sygn. 61, k. 82, 85v i sygn. 62, k. 40v. W. Wilczkowski był dowódcą tej chorągwi od ok. $1653 \mathrm{r}$. (wówczas chorągiew ta należała do wojewody sandomierskiego, a następnie krakowskiego Władysława Mysz-
} 
kwartału I667 r. (3I VII) ${ }^{9}$. Następny zachowany rejestr dla tej jednostki pochodzi z maja I673 r. - i w nim nie spotkamy już nazwiska Boratyńskiego ${ }^{10}$, w przeciwieństwie do wykazu towarzystwa chorągwi husarskiej marszałka wielkiego i hetmana wielkiego koronnego Jana Sobieskiego. W tym przypadku, co zostało już w historiografii dowiedzione, mamy pewność, że pod wymienionym w I673 r. w spisie towarzystwa husarii hetmańskiej Boratyńskim kryła się osoba późniejszego porucznika i podczaszego żydaczowskiego ${ }^{\text {II }}$. Nie wiemy, kiedy dokładnie Boratyński zaciągnął się do chorągwi hetmańskiej Sobieskiego. Wiemy jednak, że w momencie przeprowadzania aukcji wojska na potrzeby rozbudowy jednostek do etatu wojennego w maju I673 r. Boratyński widniał w składzie chorągwi hetmańskiej wśród starej kadry ${ }^{12}$, musiał zatem zaciągnąć się do tego oddziału jeszcze przed I673, ale nie wcześniej niż w I668 r. Poprzedni wykaz chorągwi Sobieskiego, który znamy, pochodzi właśnie z pierwszego kwartału I668 r. - i w nim nie spotkamy nazwiska Boratyńskiego ${ }^{13}$. Jest wielce prawdopodobne, że po I668 r. przyszły podczaszy żydaczowski przeszedł z chorągwi Lubomirskiego do roty husarskiej hetmana wielkiego, co pośrednio można łączyć z faktem, że przed I67I r. husaria wojewody krakowskiego znalazła się w składzie pułku Sobieskiego ${ }^{\mathrm{I}}$, którym dowodził porucznik roty hetmańskiej, chorąży sanocki Aleksander Polanowski. Przynależność chorągwi Lubomirskiego do tego samego pułku co chorągiew Sobieskiego mogła stanowić naturalny pomost w zmianie jednostki przez Boratyńskiego. W ten sposób możemy przyjąć, że nasz bohater rzeczywiście służył w jednostce koniuszego koronnego od I sierpnia I666 r. Czy był to jednak początek jego służby, czy też może kolejny oddział, w którym zdobywał swe żołnierskie doświadczenia - tego nie wiemy.

Boratyński był towarzyszem chorągwi Sobieskiego do I676 r. - do momentu, gdy został powołany na funkcję oficerską. W dniu I8 czerwca sporządzana została umowa, tzw. kapitulacja, na podstawie której wojewoda chełmiński Jan Gniński powierzył Boratyńskiemu funkcję porucznika w swojej chorągwi husarskiej. Gniński zapisał: „Z łaski JKM PMM otrzymawszy list przypowiedni na wystawienie chorągwi usarskiej sto dwadzieścia koni, zaciągnąłem na porucznikostwo jmp. Jacka Boratyńskiego, towarzysza roty husarskiej JKM PMM" "15. Ten zapis stanowi główny dowód na to, że służący uprzednio w rocie husarskiej

kowskiego). Nowe ustalenia nt. Wilczkowskiego na marginesie edycji jego testamentu z 1683 r. zob. J.J. Sowa, „Dysponuje krwawa pracę moję”. Testamenty oficerów wojska koronnego z ksiag grodzkich lwowskich z lat 80 . XVII wieku, „Biblioteka Epoki Nowożytnej”, 5/2017: Hortus bellicus. Studia z dziejów wojskowości nowożytnej, red. K. Bobiatyński et al., s. 583-606.

9 Zob. rejestry popisowe chorągwi husarskiej koniuszego koronnego A.M. Lubomirskiego w okresie służby III kwartał 1663 - II kwartał 1667, AGAD, Akta Skarbowo-Wojskowe (dalej: ASW), dz. 85, sygn. 96, k. 31-41; zob. też E. Janas, L. Wasilewski, Społeczne aspekty rozwoju husarii w latach 1648-1667 na przykładzie choragwi hetmana wielkiego koronnego Stanisława Potockiego i wojewody sandomierskiego Władysława Myszkowskiego, „Studia i Materiały do Historii Wojskowości”, 23/1981, s. 65-112.

10 Rejestr popisowy chorągwi husarskiej wojewody krakowskiego A.M. Lubomirskiego w II kwartale 1673, AGAD, ASW, dz. 82, sygn. 16, s. 39-40.

11 Z. Hundert, Husaria koronna..., s. 179, 198, 216; idem, Choragiew husarska..., s. 121, 131; por. M. Wagner, Stownik biograficzny..., s. 30, hasło: Boratyński Jacek.

12 Rejestr chorągwi husarskiej J. Sobieskiego w II kwartale 1673, AGAD, ASW, dz. 85, sygn. 104, k. $142-143$.

13 Rejestr chorągwi husarskiej J. Sobieskiego w I kwartale 1668, AGAD, ASK, dz. III, sygn. 5, k. 1154.

14 Z. Hundert, Husaria koronna..., s. 268-269; idem, Między buława a tronem. Wojsko koronne w walce stronnictwa malkontentów z ugrupowaniem dworskim w latach 1669-1673, Oświęcim 2014, s. 165, 317.

15 Kapitulacja wojewody chełmińskiego J. Gnińskiego z Jackiem Boratyńskim (z podpisem Boratyńskiego), Jaworów, 18 VI 1676, AGAD, Archiwum Zamoyskich (dalej: AZ), sygn. 3112, s. 451 (dawna paginacja: k. 288). 
Sobieskiego Boratyński to Jacek, późniejszy porucznik i podczaszy żydaczowski. Boratyński służył na czele pocztu trzykonnego w chorągwi hetmańskiej, po 2I maja I674 r. królewskiej (po elekcji Jana III), nieprzerwanie od drugiego kwartału I673 do drugiego kwartału I676 $6^{16}$. Zapewne odbył też wszystkie działania wojenne, w których uczestniczyła chorągiew husarska Sobieskiego, jak np. w bitwie pod Chocimiem IO-II listopada I673, kampanii bracławskiej I674-I675, bitwie pod Niemirowem 28 stycznia I675, czy bitwie pod Lwowem/Lesienicami 24 sierpnia $1675 \mathrm{r} \cdot{ }^{17} \mathrm{~W}$ momencie powołania Boratyńskiego na funkcję porucznika w innej chorągwi husarskiej, tj. w czasie drugiego kwartału I676, w swojej jednostce zajmował nie najwyższe, ale relatywnie wysokie miejsce w hierarchii towarzystwa - tj. plasował się na pozycji I9. wśród 56 towarzyszy ${ }^{18}$. Mimo objęcia funkcji porucznika w dniu I8 czerwca nazwisko Boratyńskiego występowało jeszcze na czele pocztu dwukonnego w ramach chorągwi królewskiej Jana III w następnym kwartale służby, liczonym od I sierpnia do 3I października. Tę zależność należy tłumaczyć tym, że na czas kampanii i676 r. Boratyński, jako porucznik innego oddziału, pozostawił swój poczet w rocie królewskiej na potrzeby działań wojennych, zakończonych rozejmem zawartym z Portą pod Żurawnem $\mathrm{I} 7$ października ${ }^{19}$.

Boratyński został w I676 r. porucznikiem jednej z siedmiu nowo utworzonych chorągwi husarskich, które do służby koronnej w trybie jazdy kopijniczej miały wejść I maja (sześć z nich powstało z ,pohusarzenia” rot pancernych, siódma była formowana od podstaw). Utworzenie tylu jednostek, co podnosiło liczbę koronnych chorągwi husarskich o 50\% (z I4 na 2I jednostek), związane było z chęcią stanowczego zwiększenia siły uderzeniowej armii Rzeczypospolitej w przeddzień kampanii wojennej, która jak wierzono, miała przynieść rozstrzygnięcie ${ }^{20}$. Do wystawienia nowych jednostek husarskich poszukiwano odpowiednich ludzi - tu zgłosił się m.in. Jan Gniński, osoba dość blisko związana z Janem III ${ }^{21}$. Najpierw objął on chorągiew pancerną kasztelana kijowskiego Mariusza Jaskólskiego, a następnie rozpoczął proces przezbrojenia jej na husarskąa ${ }^{22}$. Nie dysponujemy na to bezpośrednimi dowodami, ale jest wysoce prawdopodobne, że to król polecił towarzysza swojej chorągwi wojewodzie chełmińskiemu, by podjął się funkcji porucznika w powstającej jednostce jazdy kopijniczej. Sugeruje to choćby miejsce zawarcia kapitulacji pomiędzy Gnińskim i Bora-

\footnotetext{
16 Rejestry chorągwi husarskiej J. Sobieskiego, II kwartał 1673 - I kwartał 1674 oraz I kwartał 1674 - IV kwartał 1676, AGAD, ASW, dz. 85, sygn. 104, k. 142-147 i sygn. 108, k. 78v-90. Wszystkie te rejestry zostały wydane drukiem: Z. Hundert, Husaria koronna..., s. 435-440 (aneks 3).

17 Z. Hundert, Husaria koronna ..., passim. Więcej o działaniach wojennych w latach 1673-1676 zob. M. Wagner, Wojna polsko-turecka w latach 1672-1676, t. 1-2, Zabrze 2009.

18 Rejestr chorągwi husarskiej J. Sobieskiego, II kwartał 1676, AGAD, ASW, dz. 85, sygn. 108, k. 87v-88. Był to stopniowy awans, 3 lata wcześniej bowiem, w II kwartale 1673, zajmował miejsce 25. na 40 towarzyszy starej kadry (ibidem, sygn. 104, k. 142-143).

19 Z. Hundert, Husaria koronna..., s. 260; idem, Choragiew husarska ..., s. 121. Więcej o rozejmie w Żurawnie zob. M. Wagner, Wojna polsko-turecka ..., t. 2, s. 281-287.

20 Z. Hundert, Husaria koronna..., s. 116-128; por. J. Wimmer, Wojsko polskie w drugiej połowie XVII wieku, Warszawa 1965, s. 190-192.

21 A. Przyboś, Gniński Jan, w: Polski Słownik Biograficzny, t. 8, 1959, s. 149-151. Gniński, podobnie do Sobieskiego, wielkiej polityki uczył się u boku Jana Kazimierza i Ludwiki Marii. Był powszechnie zaliczany do tzw. ludzi nowych, którym sojusz z dworami kolejnych monarchów popłacał, w celu zbudowania materialnej pozycji rodziny. Gniński był zresztą pierwszym przedstawicielem rodu, który uzyskał godność senatorską; por. S. Ciara, Senatorowie i dygnitarze koronni w drugiej połowie XVII wieku, Wrocław-Warszawa-Kraków 1990, passim.

22 Z. Hundert, Husaria koronna ..., s. 122. Gniński wszedł w posiadanie chorągwi zapewne ze względu na koneksje rodzinne, był on bowiem spowinowacony z Jaskólskimi poprzez żonę, Dorotę z Jaskólskich.
} 
tyńskim, co dokonało się w Jaworowie - w jednej z głównych rezydencji Jana III ${ }^{23}$. Nie był to bynajmniej pierwszy raz, gdy towarzysz z chorągwi Sobieskiego został porucznikiem w jednostce należącej do politycznych sojuszników zasiadającego na tronie od I674 r. Jana III. Gdy przed I669 r. przyjaciel i jeden z głównych współpracowników ówczesnego hetmana i marszałka - pisarz polny koronny Jakub Potocki (zm. I67I) wystawił swoją chorągiew husarską, jej porucznikiem został towarzysz roty hetmańskiej - Stanisław Jan Achingier ${ }^{24}$. Zresztą, chorągiew husarska Sobieskiego od momentu objęcia jej przez późniejszego króla w I667 r. stała się ośrodkiem szkolącym przyszłą kadrę dowódczą, a Boratyński był tylko kolejną osobą, która potwierdzała tę zależność ${ }^{25}$.

Boratyński zostając porucznikiem husarskim w chorągwi Gnińskiego I8 czerwca I676 r., mocą kapitulacji został zobowiązany do zorganizowania jednostki. Otrzymał pozwolenie zrealizowania asygnacji na żołd dla chorągwi i na rozdzielenie środków między towarzystwo. Od Gnińskiego miał otrzymać także 5000 zł na groty do kopii, przy czym patron zapewnił go, że sztandar, kopie i proporce sam ufunduje we Lwowie, miejscu koncentracji armii na kampanię 1676 r. Gniński ustąpił Boratyńskiemu dochód płynący ze ślepych pocztów, w celu utrzymania przy chorągwi muzyki czy na pokrycie nieprzewidzianych wydatków. Do tego Boratyński uzyskał roczną pensję w wysokości 4000 zł, w zamian czego: „Pan Porucznik reciproce wszelkie staranie koło erekcyjej i konserwacyjej chorągwi pomienionej na się bierze i sprawować ją w obozach na każdym miejscu zawsze będzie dla wspólnej sławy naszej, wszelkich krzywd na konsystencjach i w ciągnieniu przestrzegając, żeby to było z jak największą u JKM i Rzptej przysługą i honorem imienia mego". Przy okazji, kapitulacja zobowiązywała porucznika, by stawił się w obozie wojska z gotową jednostką do końca sierpnia, a przynajmniej nie później niż Io września ${ }^{26}$. Sformowanie nowych chorągwi husarskich w 1676 r. okazało się zadaniem wręcz niewykonalnym. Żadna z nich nie wzięła udziału w kampanii żurawińskiej, a tylko dwie dotarły do obozu wojska we Lwowie, gdzie organizowano korpus posiłkowy ${ }^{27}$. Chorągiew Gnińskiego pod Boratyńskim, mimo iż sam wojewoda chełmiński znajdował się w trakcie działań wojennych jesienią I676 r. we Lwowie, nie dotarła do miejsca zbornego, za co - podobnie jak 4 inne chorągwie husarskie - została

${ }^{23}$ Zob. np. J. Woliński, Warszawa czasów Sobieskiego jako ośrodek dyspozycji politycznej, „Rocznik Warszawski", 7/1966, s. 115.

24 Z. Hundert, Między buława a tronem..., s. 73, 150-151, 175; idem, „Kopijników, czyli husarzy choragwie, owo czoło wojska, owa nieodparta w wojnie potęga, powinny być pomnożone" - Hetman Jan Sobieski a husaria koronna w latach 1667-1673, w: Marszalek i hetman koronny Jan Sobieski i jego czasy (1665-1674), red. D. Milewski, Warszawa 2014, s. 258, 266.

${ }^{25}$ Boratyński był co najmniej dziewiątym towarzyszem chorągwi husarskiej Sobieskiego, który w latach 1667-1676 uzyskał funkcję dowódczą. Przed nim byli to: w 1667 r.: Michał Wilmont i Piotr Branicki (obaj na rotmistrzów jazdy lekkiej); ok. 1668/1669 S.J. Achingier (porucznik husarski); w 1673 r.: Marcin Cieński (rotmistrz pancerny), Michał Wasilkowski, Krzysztof Chełmski (porucznicy pancerni); w 1674 r. Michał Wilkoński (porucznik pancerny); w 1675 r. Michał Kazimierz Pusłowski (chorąży husarski w kompucie litewskim); zob. Z. Hundert, Między buława a tronem..., s. 174-175; idem, „Kopijników, czyli..., s. 266; idem, Husaria koronna ..., 196-198; idem, Choragiew husarska..., s. 129-132.

${ }^{26}$ Kapitulacja wojewody chełmińskiego J. Gnińskiego z Jackiem Boratyńskim, Jaworów, 18 VI 1676, AGAD, AZ, sygn. 3112, s. 451. Treść aktu, wraz z omówieniem: Z. Hundert, Husaria koronna ..., s. 250-253; M. Wagner, Korpus oficerski wojska polskiego w drugiej połowie XVII wieku, Oświęcim 2015, s. 87-88.

27 O organizacji korpusu posiłkowego dla oblężonych pod Żurawnem wojsk Jana III zob. M. Wagner, Wojna polsko-turecka ..., t. 2, s. 287-294; Z. Hundert, Husaria koronna ..., s. 404-408. 
odsądzona od wypłaty żołdu za czwarty kwartał $1676 \mathrm{r}^{28}$ Wiemy jednak, że husarze pod Boratyńskim podejmowali próbę dotarcia do Lwowa. Sam Gniński donosił bowiem Janowi III pod koniec września, że jego rota czwarty tydzień maszerowała z Babiego Mostu (Babimostu) w kierunku stolicy województwa ruskiego ${ }^{29}$. Do celu, przed podpisaniem rozejmu I7 października, jednak nie dotarła - w ten sposób Boratyński stracił szansę odbycia swej pierwszej kampanii wojennej w dystynkcji oficerskiej.

Po ustaniu wojny tureckiej chorągiew husarska pod Boratyńskim została przedstawiona do dystrybuty hiberny w sile I2O koni, w składzie pułku wojewody ruskiego i hetmana polnego koronnego Stanisława Jana Jabłonowskiego ${ }^{30}$. Następnie przetrzymała redukcję wojska i w nowym kompucie, obowiązującym od I maja I677 r., znalazła się wśród chorągwi pułku hetmana polnego w wielkości 80 koni $^{3{ }^{1}}$. Od tego też momentu - co będzie jeszcze później omawiane - Boratyński w zasadzie do końca XVII w. pozostawał oficerem hetmańskiego pułku kawalerii. W ten sposób funkcjonował w strukturze wojskowej znajdującej się w bezpośredniej strefie wpływów wojewody ruskiego i hetmana polnego, a od $\mathrm{I} 683 \mathrm{r}$. wielkiego. W I677 r. oprócz redukcji wprowadzono także stałą dyslokację sił koronnych na nie uformowanej jeszcze granicy z Wysoką Portą. Chorągiew Gnińskiego pod Boratyńskim weszła w skład partii hetmana polnego (w ramach jego pułku jazdy) pod Trembowlą w ziemi halickiej ${ }^{2}$. Boratyński nie ruszył jednak w tym czasie na wyznaczone mu miejsce, udał się bowiem w składzie poselstwa patrona swojej roty, J. Gnińskiego, do Stambułu. Widać zatem, że Gniński cenił swojego porucznika, uważając, że jego udział w poselstwie jest nieodzowny.

Boratyński udał się w drogę włącznie z grupą towarzystwa $\mathrm{z}$ dowodzonej przez siebie chorągwi. Był niewątpliwie jednym $z$ najbardziej zaufanych kompanów osoby pierwszego posła ${ }^{33}$. Dane mu było uczestniczyć, jako jednemu z nielicznych członków poselstwa, w pierwszej audiencji u sułtana I2 września I677 r. i w wieńczącym ją wieczornym bankiecie ${ }^{34}$.

28 Z. Hundert, Husaria koronna ..., s. 127, 407-408. Warto dodać, że rotmistrz jednej z siedmiu nowo utworzonych chorągwi husarskich - podstoli lwowski Marcin Zamoyski - donosił pod koniec maja 1676 r. swojemu teściowi, J. Gnińskiemu: „Usarskiej chorągwi żądną miarą wystawić nie mogę, gdyż na żadną majętność nie chcą mi dać ani na zastaw, ani na arendę. Uczyniłbym już to na rozkazanie WMM pana dobro[dzieja] i na przysługę JKM PMM ale Deus testor że żadnego nie mam sposobu zaciągnienia pieniędzy, cóż tedy mam czynié" (M. Zamoyski do J. Gnińskiego, Lublin, 23 V 1676, AGAD, AZ, sygn. 455, s. 136). Mimo to, trudności zostały przezwyciężone i rota Zamoyskiego, częściowo przystosowana do trybu husarskiego, weszła do obozu wojska pod Lwowem, jeszcze przed 29 IX 1676 (Z. Hundert, Husaria koronna ..., s. 278-279, 404-406).

29 J. Gniński do Jana III, Lwów, 29 IX 1676, w: Materiały do dziejów wojny polsko-tureckiej 1672-1676, oprac. J. Woliński, „Studia i Materiały do Historii Wojskowości”, 16/1970, cz. 2, s. 242; Z. Hundert, Husaria koronna..., s. 404-406.

${ }^{30}$ Komput wojska polskiego zaciagu koronnego ex senatus consilis ordynowany $i$ dla hiberny podany, Lwów 24 XI 1676, Biblioteka XX. Czartoryskich w Krakowie (dalej: B. Czart.), rkps 174, s. 438-444 i rkps 426, s. 505520, AGAD, AZ, sygn. 3112, s. 456-460 (druk: Materiały do dziejów..., „Studia i Materiały do Historii Wojskowości”, 16/1970, cz. 2, s. 254-259).

31 Zob. np. rachunki skarbowo-wojskowe za lata 1677-1679, AGAD, ASW, dz. 86, sygn. 65, s. 31-32 i nn. Komputy wojska koronnego z 28 IV 1677, z podpisem hetmana wielkiego koronnego Dymitra Wiśniowieckiego oraz króla Jana III, ibidem, sygn. 61 k. 31-33v, 38-40v.

32 Z. Hundert, Dyslokacja partii wojska koronnego w 1677 roku. Przyczynek do badań pogranicza polsko-tureckiego oraz organizacji armii w dobie pokoju 1677-1683, „Klio”, 1(36)/2016, s. 52.

33 Warto dodać, że drugim rangą posłem był pułkownik wojska koronnego - i również porucznik husarski (w rocie wojewody podlaskiego Wacława Leszczyńskiego), starosta chełmski, Michał Florian Rzewuski; zob. M. Nagielski, Rzewuski Michat Florian, w: Polski Stownik Biograficzny, t. 34, 1992, s. 130-133.

${ }^{34}$ Relacja legacyi tureckiej jaśnie wielmożnego Jana Gnińskiego, wojewody chetmińskiego, kowalewskiego, knyszyńskiego, grodeckiego, radzyńskiego starosty, do Mechmed soltana, cesarza konstantynopolskiego z sejmu war- 
W końcu I677 r. Boratyński miał być wykorzystany przez Gnińskiego do dostarczenia małżonce i zięciowi Marcinowi Zamoyskiemu (wówczas już kasztelanowi lwowskiemu) korespondencji oraz diariusza wydarzeń - ale ostatecznie Turcy nie wyrazili zgody na jego wyjazd i w połowie grudnia, na czele części orszaku, do kraju ruszył pierwszy w rejestrze towarzystwa roty Gnińskiego Wojciech Prusak ${ }^{35}$. Jak zanotowano w diariuszu poselstwa: „Miałci wprawdzie sam P. porucznik powracać dla gwałtownych interesów swoich w ojczyźnie - razem z innym dostojniejszymi przedstawicielami poselstwa - ale ich żadną miarą puścić nie chciano, i regestr od wezyra [Kara Mustafy - Z.H.] przyniesiono - i tych osób, które tu zostać musiały, i tych, co im w drogę kazano" ${ }^{36}$. Związane to było po części z zarazą, której ofiarą padali członkowie orszaku, w tym czeladnik (pocztowy) Boratyńskiego nazwiskiem Czerkawski ${ }^{37}$. W związku z morowym powietrzem w styczniu I678 r. porucznik wojewody chełmińskiego znalazł się dla kwarantanny w Galacie ${ }^{38}$.

Na marginesie warto dodać, że w trakcie poselstwa Gniński zadbał o zobowiązania finansowe wobec swojego porucznika, który w grudniu 1677 r. wystawił kwit potwierdzający odbiór jurgieltu. Boratyński oświadczył w tym dokumencie, że połowę pensji za rok I677, tj. 2000 zł, odebrał jeszcze w Warszawie, następne 600 zł pobrał przez pośrednika, zaś w Stambule I8 października otrzymał I200 zł. Do pełnego rozliczenia brakowało 200 zł, które Gniński wypłacił porucznikowi 6 grudnia ${ }^{39}$.

Udział w poselstwie Gnińskiego nie pozostał bez wpływu na dalszy rozwój kariery porucznika, mimo że misja dyplomatyczna ostatecznie zakończyła się fiaskiem ${ }^{40}$. Wojewoda chełmiński podczas sejmu grodzieńskiego, w dniu 8 lutego I679, dwukrotnie zalecał Boratyńskiego łasce króla - w mowie poprzedzającej czytanie relacji oraz w samym sprawozdaniu z poselstwa do Stambułu ${ }^{41}$. Za tą protekcją Gnińskiego Jan III docenił trudy pobytu w stolicy Imperium Osmańskiego dawnego towarzysza swojej chorągwi i Boratyński został uhonorowany przez władcę pod koniec I679 r. urzędem ziemskim cześnika sanockiego po uprzednim awansowaniu na podsędka lwowskiego innego porucznika jazdy kopijniczej (w rocie starosty lwowskiego Jana Cetnera), Andrzeja Kamińskiego, co dokonało się 15 listopada $^{42}$. W ten sposób po zidentyfikowanych trzynastu latach służby wojskowej w szeregach husarii, w tym po trzech latach w dystynkcji oficerskiej, Boratyński uzyskał swój pierwszy

szawskiego wyprawionego, w roku pańskim 1677, czyniona na sejmie w Grodnie dnia 8 miesiaca februarii roku pańskiego 1679, w: Źródta do poselstwa Jana Gnińskiego, wojewody chetmińskiego do Turcyi w latach 1677-1678, oprac. F. Pułaski, Warszawa 1907 (dalej: Relacja legacyi), s. 38. Można się zgodzić z M. Wagnerem, że Boratyński sprawował wówczas funkcję dowódcy straży przybocznej posła; idem, Słownik biograficzny..., s. 30, hasło: Boratyński Jacek.

35 Zob. J. Gniński do M. Zamoyskiego, Stambuł, 9, 16, 22 XII 1677, w: Źródła do poselstwa..., s. 267, 272-273, 281 .

${ }^{36}$ Relacja legacyi, s. 61; por. J. Gniński do M. Zamoyskiego, Stambuł, 22 XII 1677, w: Źródła do poselstwa..., s. 281; zob. też Z. Hundert, Husaria koronna..., s. 261 (w kwestii W. Prusaka).

37 Relacja legacyi, s. 63.

38 Ibidem, s. 64, 108.

39 Kwit Boratyńskiego na potwierdzenie odbioru pieniędzy z jurgieltu, Stambuł, 6 XII 1677, w: Źródła do poselstwa ..., s. 449; por. Z. Hundert, Husaria koronna ..., s. 253.

40 O przebiegu poselstwa i jego skutkach zob. np. D. Kołodziejczyk, Podole pod panowaniem tureckim. Ejalet kamieniecki 1672-1699, Warszawa 1994, s. 86-96; M. Wagner, Wojna polsko-turecka ..., s. 2, s. 305-308.

${ }^{41}$ Mowa J. Gnińskiego na sejmie grodzieńskim poprzedzająca czytanie relacji, Grodno, 8 II 1679, w: Źródła do poselstwa..., s. 427; Relacja legacyi, s. 195.

42 Urzędnicy województwa ruskiego, s. 138, 259. O A. Kamińskim zob. Z. Hundert, Husaria koronna..., s. 214. 
urząd ziemski. W roku następnym, również za protekcją Gnińskiego, dostał w dzierżawę wieś Bystrzyce w województwie sandomierskim (powiat pilzneński) ${ }^{43}$. Związki nieformalne z osobą patrona swojej jednostki, zacieśnione niewątpliwie podczas poselstwa do Stambułu w latach I677-I678, zaczęły przynosić profity.

Kolejne lata funkcjonowania wojska w ramach komputu pokojowego, czyli do czasu powiększenia armii na czas kampanii wiedeńskiej w maju I683 r., nie przyniosły Boratyńskiemu większych zmian. W zasadzie tylko dwie są warte odnotowania. Po pierwsze, patron cześnika sanockiego awansował najpierw na wojewodę malborskiego (przełom I680 i I68I), następnie w marcu I68I r., po wstąpieniu do stanu duchownego (żona zmarła w I679 r.), na podkanclerzego koronnego ${ }^{44}$. Druga kwestia to wprowadzenie w I679 r. systemu płacy w ramach repartycji, czyli opłacania jednostek przez samorządy lokalne, z pomięciem skarbu centralnego. Chorągiew husarska Gnińskiego została wówczas oddana na żołd województwom Prus Królewskich, co skutkowało wejściem Boratyńskiego i jego podkomendnych w bliższe relacje z tym obszarem ${ }^{45}$.

W I683 r., gdy postanowiono rozbudowę wojska do etatu wojennego, chorągiew księdza podkanclerzego powiększono do stanu $\mathrm{I} 20 \mathrm{koni}^{46}$. W systemie repartycji nadal miała przynależeć do województw pruskich ${ }^{47}$, a w kampanii wiedeńskiej wzięła zapewne udział w składzie pułku hetmana wielkiego S.J. Jabłonowskiego ${ }^{48}$. Boratyński w dalszym ciągu stał na czele tej chorągwi, co podkreślił w swoim dziele na temat wyprawy i bitwy pod stolicą cesarską zabrany na kampanię królewski historiograf - Wespazjan Kochowski ${ }^{49}$. W bitwie wiedeńskiej I2 września I683 r. Boratyński na czele swojej chorągwi obok jednostek husarskich starosty szczurowieckiego Aleksandra Cetnera i wojewody płockiego Samuela Prażmowskiego (obie z pułku królewskiego) został oddelegowany na lewe skrzydło szyku wojsk sprzymierzonych pod komendę ks. Karola Lotaryńskiego ${ }^{50}$. W ten sposób, Boratyński, który w randze porucz-

43 M. Wagner, Słownik biograficzny..., s. 30, hasło: Boratyński Jacek.

44 S. Ciara, op. cit., s. 21.

45 Podział wojska JKM i Rzptej obojga zaciagów na województwa i ziemie na trybunale skarbowym lwowskim in anno 1679 uczyniony, B. Czart., rkps 426, s. 173-176; Z. Hundert, Wykaz koronnych choragwi i regimentów w okresie od 1 V 1679 do 30 IV 1683. Przyczynek do organizacji wojska koronnego w dobie pokoju 1677-1683, w: Studia Historyczno-Wojskowe, t. 5, red. M. Nagielski, K. Bobiatyński, P. Gawron, Zabrze-Tarnowskie Góry 2015, s. 275-276, 278; idem, Wykaz repartycji jednostek wojska koronnego, zgodnie z podziatem komisji lwowskiej w 1679 roku, „Przegląd Historyczno-Wojskowy”, 58/2016, z. 2-3, s. 31.

${ }^{46}$ Komput wojsk JKM i Rzptej polskiego i cudzoziemskiego zaciagu, starego i nowego, podtug ordynacjej Rzptej na sejmie anni 1683 uczynionej i postanowionej, B. Czart., rkps 2563, s. 9.

47 Podziat wojska JKM i Rzptej koronnego starego i nowego zaciagu ad proportionem podatków na sejmie anni

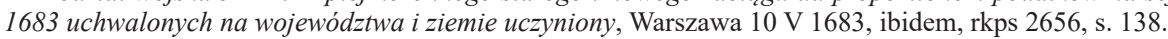

48 Jedyny znany dokument, który ukazuje podział chorągwi husarskich oraz pancernych na pułki w 1683 r., w ogóle nie uwzględnia chorągwi husarskiej J. Gnińskiego, choć ta bez wątpienia brała udział w kampanii wiedeńskiej. Wydaje się, że przyczyną tego stanu rzeczy było po prostu zwykłe przeoczenie podczas sporządzania aktu; zob. Komput wojska koronnego z aktów komisji dystrybuty hibernowej ex anno 1683 in annum 1684 za szczęśliwym powrotem z wiedeńskich i strygońskich okazyi najjaśniejszego króla jmści Jana Trzeciego, za buławy jmp. wojewody ruskiego Stanisława Jabłonowskiego, HWK, a polnej Mikołaja Sieniawskiego, wojewody wołyńskiego, HPK, B. Czart., rkps 2589, s. 97-102; por. J. Wimmer, Wiedeń 1683. Dzieje kampanii i bitwy, Warszawa 1983, s. 220.

49 W. Kochowski, Commentarius belli adversum Turcas ad Viennam, \& in Hungaria, Anno CH: M.DC.LXXXIII. Gesti, ductu \& auspicic serenissimi ac potentissimi Ioannis III, Regis Poloniarum, Mag: Duc: Lithuanie, Kraków 1684, s. 32. 50 Relatio a comitiis anni 1683 biennalium gestorum et laborum exercitus tam in horizontibus Viennensibus \& Hungaricis, quam Podoliensibus, \& Subistrensibus sub clava Stanislai Jabłonowski, palatini \& generalis terrarum Russiae, ducis supremi Regni ad eodem facta, w: Epistolarum historico-familiarum, t. 1, cz. 2, ed. A.Ch. Załuski, 
nika po raz pierwszy dowodził husarią w większej bitwie, dostał odpowiedzialne zadanie służyć wsparciem wojskom cesarskim - a zarazem pokazać sojusznikom z bliska jakość polskiego żołnierza. Cześnik sanocki i jego husarze musieli sprawić się wyjątkowo dobrze, podczas bitwy, jak również podczas kolejnych działań w ramach kampanii I683 r., stali się bowiem beneficjantami królewskich łask. Najpierw Jan III Io stycznia I684 w Krakowie nadał towarzyszowi chorągwi Gnińskiego - Mikołajowi Łastowieckiemu urząd podstolego bracławskiego (po zmarłym Tomaszu Gajewskiem), następnie I5 dni później uhonorował samego porucznika. Boratyński za udział w kampanii wiedeńskiej został mianowany podczaszym żydaczowskim - po uprzednim awansie Konstantego Wapowskiego na urząd chorążego sanockiego ${ }^{51}$. W ten sposób, dzięki postawie w działaniach I683 r., Boratyński osiągnął swój ostatni w karierze awans urzędniczy. Z postawą w kampanii należy łączyć również fakt, że W I683 r. Boratyński został wybrany jednym z pięciu wojskowych komisarzy do podziału hiberny, co było dość prestiżowym i odpowiedzialnym zadaniem ${ }^{52}$.

W I684 r. ksiądz podkanclerzy, zapewne ze względu na zły stan zdrowia (zmarł już w następnym roku), swoje oddziały wojskowe - w tym przede wszystkim husarię pod Boratyńskim, scedował na syna Jana Krzysztofa, wojewodę czernihowskiego, a od I685 r. bracławskiego. Nowy patron chorągwi również spisał z Boratyńskim akt kapitulacji, co dokonało się 24 czerwca I684 r. W ten sposób podczaszy żydaczowski jest obecnie jedynym znanym przykładem husarskiego porucznika, dla którego zachowały się akty kapitulacji, zawarte z dwoma kolejnymi patronami chorągwi. Porozumienie między wojewodą czernihowskim a jego porucznikiem było w zasadzie powtórzeniem zapisów umowy Boratyńskiego z poprzednim zwierzchnikiem z czerwca I676 r. Podczaszy żydaczowski miał w dalszym ciągu pobierać jurgielt w wysokości 4000 zł, a także czerpać dochód z pocztów rotmistrzowskich, w celu utrzymywania przy chorągwi porządnej muzyki. Kapitulacja zobowiązywała porucznika, podobnie jak ta poprzednia, do stałego przebywania przy chorągwi i zajmowania się jej bieżącymi problemami, czyli sprawami koło erykcyi $i$ konserwacyi $[\ldots]$ w obozach $i$ na każdem miejscu ${ }^{53}$. Co jest równie istotne - poprzednia kapitulacja została zawarta w siedzibie Jana III w Jaworowie, ta z czerwca I684 r. - w Busku, a więc w siedzibie hetmana wielkiego Jabłonowskiego. Było to bez wątpienia powiązane z faktem, że Boratyński ze swoją chorągwią znajdował się w strefie oddziaływań wojskowego patronatu hetmana, poprzez przynależność do pułku jazdy Jabłonowskiego. Przydział ten został utrzymany, gdy husarię ojca objął J.K. Gniński, co potwierdzają liczne komputy wojska koronnego z lat osiemdziesiątych i dziewięćdziesiątych XVII w. Rota kopijników wojewody bracławskiego, a od I694 r. pomorskiego była odnotowana w składzie pułku Jabłonowskiego (od I692 kasztelan krakowski) do końca wojny z Turcją w I699 r. - m.in. w komputach z lat I686, I687, I689,

\footnotetext{
Brunsbergae (Braniewo) 1710, s. 844; J. Wimmer, Wiedeń 1683..., s. 300. Zob. też R. Sikora, Husaria pod Wiedniem 1683, Warszawa 2012, s. 143, 226, 242-243.

51 Akta grodzkie i ziemskie z czasów Rzeczypospolitej Polskiej z archiwum tak zwanego bernardyńskiego we Lwowie, t. 10: Spis oblat zawartych w aktach grodu i ziemstwa lwowskiego, oprac. K. Liske, Lwów 1884 (dalej: Spis oblat), s. 350-351; Urzędnicy województwa ruskiego, s. 175.

52 Rachunki sejmu 1685 r., AGAD, ASK, dz. II, sygn. 68, k. 26.

53 Kapitulacja J.K. Gnińskiego z J. Boratyńskim, Busk, 24 VI 1684, w: K. Górski, Historya jazdy polskiej, Kraków 1894, s. 328. Podstawa wydania: Biblioteka Ordynacji Krasińskich, rkps 708, s. 208: rękopis zniszczony w 1944 r.; por. J. Wimmer, Wojsko polskie..., s. 260, przyp. 1; Z. Hundert, Husaria koronna ..., s. 253; M. Wagner, Korpus oficerski..., s. 88 .
} 
I690 i I69854. Zgodnie z reorganizacją etatu koronnego z I69o r. chorągiew Gnińskiego liczyła już nie I20, a IOo koni, ponadto zmienił się jej przydział w systemie repartycji - żołd miała bowiem odbierać nie od województw Prus Królewskich, a od województwa krakowskiego ${ }^{55}$. Po zakończeniu wojny z Portą w I699 r. i redukcji wojska do etatu pokojowego husaria wojewody pomorskiego w sile zaledwie 60 koni pozostała w strukturach pułku kasztelana krakowskiego i hetmana wielkiego Jabłonowskiego ${ }^{56}$. Dzięki tej zależności Boratyński w okresie wojen z Turcją w drugiej połowie XVII w. może być bez wątpliwości określany mianem oficera hetmańskiego pułku jazdy.

Przebieg służby wojskowej podczaszego żydaczowskiego po I684 r. jest o wiele trudniejszy do ustalenia niż dla lat wcześniejszych. Itinerarium bojowe Boratyńskiego było zapewne tożsame z losami dowodzonej przez niego chorągwi, był on bowiem jej faktycznym dowódcą. W związku z tym brał prawdopodobnie udział w kampaniach lat I684 i I685 (odpowiednio: żwaniecka i bukowińska) ${ }^{57}$, choć nie dysponujemy na to bezpośrednimi dowodami. Następnie uczestniczył w wyprawie mołdawskiej króla Jana III w I686 r., władca bowiem 22 września w obozie pod Sormosser nadał Boratyńskiemu wójtostwo Bartodowa w powiecie gródeckim. Nadanie królewskie mogło być formą nagrody za postawę porucznika chorągwi Gnińskiego W zakończonej ostatecznie niepowodzeniem kampanii - ale to też nie jest pewne ${ }^{5}$. Dla roku 686 zachowała się księga z rozkazami Jabłonowskiego, jednakże analiza licznych materiałów w niej zawartych nie pozwoliła zidentyfikować żadnej informacji odnoszącej się bezpośrednio do podczaszego żydaczowskiego. Jako faktyczny dowódca chorągwi Gnińskiego realizował prawdopodobnie rozkazy wydane dla tej jednostki - te zaś księga hetmańska odnotowała. Zgodnie z wolą Jabłonowskiego z marca I686 r. chorąiew, którą komenderował podczaszy żydaczowski, miała ruszyć z konsystencji zimowych pod rozkazy stolnika latyczowskiego Jana Aleksandra Wronowskiego - a gdy ten zachorował - pod rozkazy chorążego bracławskiego Nikodema Żaboklickiego ${ }^{59}$. Później ze swoją chorągwią

\footnotetext{
54 Zob. Komput wojska JKM i Rzptej na kampania in anno 1686, Biblioteka Zakładu Narodowego im. Ossolińskich we Wrocławiu (dalej: B. Ossol.), rkps 250/II, k. 144-147; Komput Wojska JKM i Rzptej na hibernę in anno 1686, ibidem, k. 148-151v; Connotatia popisu wojska JKM i Rzptej kawaleriej die 20 July pod Jagielnica odprawionego, 20 VII 1687, w: Źródta do dziejów wojny polsko-tureckiej w latach 1683-1699, oprac. M. Wagner, Oświęcim 2016, s. 77-82; Komput wojska JKM i Rzptej na kampaniej in anno 1689 z popisu generalnego w ćwierci augustowej roku tegoż, AGAD, ASW, dz. 86, sygn. 70, s. 3; Komput wojska JKM i Rzeczypospolitej koronnego na sejmie anni 1690 ad numerum 30000 redukowany i spisany, B. Czart., rkps 2562, s. 1; Komput wojsk JKM i Rzptej na kampanię in anno 1698 w obozie pod Mużylowem 17 IX reformowany, w: Materiały do dziejów kampanii podhajeckiej 1698 r., oprac. J. Wojtasik, „Studia i Materiały do Historii Wojskowości”, 15/1969, cz. 2, s. 269-280.

${ }^{55}$ Podzial wojska JKM i Rzptej z komputu na sejmie teraźniejszym anni 1690 postanowionego w skrypcie ad Archivum danym wyrażonego, ad proportionem no. 45 podymnych na tymże sejmie in vim płacy płacy wojsku pomienionemu deklarowanych uczyniony, B. Czart., rkps 2562, s. 45.

${ }_{56}$ Komput Wojska JKM i Rzptej na radzie post komicjalnej warszawskiej anni 1699, a podczas komisji hibernowej lwowskiej do skarbu hibernowego w tymże roku die 3 novembris podany, AGAD, Zbiór Czołowskiego, sygn. 17, s. 9-15. Po śmierci Jabłonowskiego w 1702 r. chorągiew Gnińskiego znalazła się w składzie pułku królewicza Augusta; zob. M. Wagner, Bitwa pod Kliszowem 19 lipca 1702 roku, Oświęcim 2013, s. 79.

57 Więcej zob. M. Wagner, Kampania żwaniecka 1684 roku, Warszawa 2013; W. Wasilewski, Wyprawa bukowińska Stanisława Jabłonowskiego w 1685 roku, Warszawa 2002. Autorzy tych prac nie odnotowali dla lat 1684-1685 aktywności Boratyńskiego oraz jego chorągwi.

58 Spis oblat, s. 356. Więcej o kampanii 1686 r. zob. Cz. Chowaniec, Wyprawa Sobieskiego do Mołdawii w 1686 r., „Przegląd Historyczno-Wojskowy”, 4/1931, z. 1, s. 1-117.

59 Rozkazy S.J. Jabłonowskiego, Busk, 9 i 19 III 1686, B. Ossol., rkps 250/II, k. 22-22v, 28v-29; M. Wagner, Stanisław Jabłonowski (1634-1702). Polityk i dowódca, t. 1, Siedlce 1997, s. 229; J.J. Sowa, Jednostki komputowe Adama Mikołaja Sieniawskiego do 1702 roku, cz. 1: Udział w działaniach wojennych do 1696 roku, w: Studia
} 
powinien znaleźć się w partii wojska regimentarza i podstolego sandomierskiego Andrzeja Chełmskiego ${ }^{60}$. Był to porucznik husarii i dowódca całego pułku Jabłonowskiego, a więc bezpośredni zwierzchnik Boratyńskiego w strukturach pułkowych.

Pod datą I6 grudnia I687 r. z urzędem podczaszego żydaczowskiego w aktach sejmiku wiszeńskiego województwa ruskiego został odnotowany Aleksander Maksymilian Fredro. Stało się to podstawą dla Marka Wagnera do sformułowania opinii, że Boratyński zmarł przed 1687 r., a opróżniony przez niego urząd zajęła inna osoba ${ }^{6}$. Nasz bohater pojawia się jednak w randze porucznika Gnińskiego i z urzędem podczaszego żydaczowskiego w księgach ziemskich lwowskich pod datą 2 listopada I693 r. Akt oblatowany do ksiąg informował o wypłaceniu przez wojewodę bracławskiego wszystkich zaległych długów swojej husarii ${ }^{62}$. W związku z tym należy odrzucić informację, że Boratyński zmarł przed I687 r. Problematyczną pozostaje jednak kwestia samego urzędu, Fredro bowiem po I687 r. konsekwentnie występował w aktach sejmikowych wiszeńskich z tytułem podczaszego żydaczowskiego ${ }^{63}$. Przypadki takie, gdy dwie bądź więcej osób tytułowało się tym samym urzędem ziemskim nie były sporadyczne, co działo się na skutek fatalnej pracy kancelarii królewskich - większej i mniejszej, wydających przywileje na urzędy, które nie były wakansami ${ }^{64}$. Problem, dlaczego podczaszostwem żydaczowkim tytułowali się równocześnie Boratyński i Fredro, w świetle znanych źródeł jest, jak na razie, nie do rozstrzygnięcia.

Boratyński pełnił powinności porucznika husarskiego J.K. Gnińskiego jeszcze w połowie lat dziewięćdziesiątych XVII stulecia. W rozliczeniach z komisją hibernową lwowską z I695 r. dowódca husarii Gnińskiego był wymieniony w wypłatach tzw. largicji (dodatkowe uposażenia dla oficerów wydawane z funduszu hibernowego) jako poseł wojskowy na sejm warszawski I695 r. Z racji odbycia funkcji poselskiej otrzymał od komisji 800 zł⒌ Poselstwo wojskowe w skład którego wchodził Boratyński, a oprócz niego także młodszy syn hetmana wielkiego, chorąży koronny Aleksander Jabłonowski, przybyło do Warszawy już po zerwaniu sejmu. W skutek tego zostało podjęte jedynie na prywatnej audiencji u króla ${ }^{66}$. Następnie Boratyński został odnotowany w aktach komisji hibernowej z I697 r., w rozliczeniach za okres konfederacji wojskowej Piotra Bogusława Baranowskiego I696-I697. Jako porucznik

nad staropolska sztuka wojenną, t. 4, red. Z. Hundert, J.J. Sowa, K. Żojdź, Oświęcim 2015, s. 216; Z. Hundert, J.J. Sowa, op. cit., s. 150.

${ }^{60}$ Zob. Konnotacja choragwi i regimentów wojska JKM i Rzptej na partie rozordynowanych pod różnemi kome[n] dami ex initiis kampaniej anni 1686, B. Ossol., rkps 250/II, k. 140-143; Rozkazy S.J. Jabłonowskiego dla różnych partii wojska, Busk, 13 IV 1686, ibidem, k. 38-39v, 47; Cz. Chowaniec, op. cit., s. 30-31.

${ }^{61}$ Laudum i instrukcja sejmiku wiszeńskiego, Sądowa Wisznia, 16 XII 1687, w: Akta grodzkie i ziemskie z czasów Rzeczypospolitej Polskiej z archiwum tak zwanego bernardyńskiego we Lwowie (dalej: AGZ), t. 22: Lauda wiszeńskie 1673-1732, oprac. A. Prochaska, Lwów 1914, s. 201-202, 212; Urzędnicy województwa ruskiego, s. 175-176; M. Wagner, Słownik biograficzny..., s. 30, hasło: Boratyński Jacek.

62 Spis oblat, s. 369.

63 Zob. akta sejmikowe wiszeńskie z 17 V 1688, 5 XII 1689, 23 IX 1690, 5 V 1692, 27 VII 1696, 1 VI 1699,16 IX 1702 w: AGZ, t. 22, s. 217, 226, 233, 243, 244, 248, 254, 284, 328, 330, 378, 382.

${ }^{64}$ Zob. np. S. Ciara, op. cit., s. 12, 14, 24; T. Zielińska, Stanisław Antoni Szczuka jako referendarz koronny w latach 1688-1699, „Kwartalnik Historyczny”, 111/2004, z. 3, s. 14-15.

65 Dokumentacja komisji hibernowej z 1695 r., B. Czart., rkps 2524, s. 57. Za informację o występowaniu Boratyńskiego w aktach tego zasobu rękopiśmiennego winny jestem wdzięczność Janowi Jerzemu Sowie.

${ }^{66}$ Zob. R. Kołodziej, ,, Ostatni wolności naszej klejnot”. Sejm Rzeczypospolitej za panowania Jana III Sobieskiego, Poznań 2014, s. 388-389. 
husarii Gnińskiego miał otrzymać $400 \mathrm{zł}$ largicji ${ }^{67}$. Jest to ostatnia znana informacja na temat Boratyńskiego. Niewykluczone zatem, że w okresie konfederacji wojskowej zakończyła się jego służba w armii koronnej. Związek Baranowskiego miał w znacznym stopniu wydźwięk antyoficerski - skonfederowane towarzystwo nie dopuszczało do siebie swoich bezpośrednich dowódców, by nie zostali oni wykorzystani przez możnych protektorów do rozwiązania konfederacji ${ }^{68}$. Boratyński, jako oficer hetmańskiego pułku jazdy (i osoba pozostająca w orbicie wpływów hetmana - w końcu był posłem wojskowym na sejm I695 r.), mógł zatem wzbudzać nieufność konfederatów. Niewątpliwie jednak sprawa ustalenia daty zakończenia służby wojskowej - oraz daty śmierci Boratyńskiego (nie wiadomo, czy były ze sobą zbieżne) wymaga kolejnych badań. W tym momencie skłonny jednak jestem wyznaczyć umowny termin zakończenia służby naszego bohatera w armii koronnej na rok zawiązania konfederacji Baranowskiego, a więc I696. Przy okazji do rozwikłania pozostają inne kwestie - jak prezentowały się koneksje rodzinne - poza tymi wskazanymi na początku niniejszych rozważań. Wiemy jedynie, z akt Metryki Koronnej, że Boratyński miał syna Samuela ${ }^{69}$, kto natomiast był jego małżonką, pozostaje nadal zagadką.

Zgodnie z powyższymi ustaleniami wiemy, że Jacek (Hiacynt) Boratyński odbył przynajmniej 30-letnią służbę wojskową - co najmniej Io lat jako towarzysz i co na najmniej 20 jako porucznik ${ }^{70}$. W tym czasie związany był tylko z jedną formacją kawaleryjską, czyli husarią, co przy uwzględnieniu „husarskiej” tradycji rodzinnej (przykład dziadka Jana Mikołaja) jest wielce wymowne. Kolejne szczeble jego służby w okresie „przedoficerskim” mają dość klasyczny układ. W randze towarzysza służył najpierw w husarskiej chorągwi „magnackiej”, następnie w hetmańskiej i królewskiej, by z tej ostatniej zostać powołanym do funkcji porucznika w husarskiej rocie „magnackiej”. Przeszedł zatem dobrą szkołę żołnierską w chorągwi Sobieskiego, która - jak mieliśmy okazję się przekonać - pełniła funkcję ośrodka przygotowującego kadrę dowódczą dla obu komputów wojsk Rzeczypospolitej. Warto jednak dodać, że w tym czasie także spośród innych chorągwi husarskich rekrutowano kadrę oficerską. Wystarczy choćby zwrócić uwagę na Balcera (Baltazara) Wilgę, po I683 r. rotmistrza, pułkownika, regimentarza i komisarza kozackiego Rzeczypospolitej (I692-I699), który w latach siedemdziesiątych służył w chorągwi husarskiej podskarbiego koronnego Jana Andrzeja Morsztyna (przeformowana z pancernej w I676 r.) ${ }^{71}$. Boratyński jako oficer wojska koronnego zanotował na swoim koncie przynajmniej dwudziestoletnią, czyli dość długą, posługę oficera husarii. Tak samo długo dowódcą husarskim był jego wcześniejszy przełożony, Aleksander Polanowski (w latach I663-I683), z tym że porucznik husarski Sobie-

\footnotetext{
${ }^{67}$ Kombinacja hibernowa warszawska 1697 r., B. Czart., rkps 2524, s. 214.

68 J.J. Sowa, Zawiązanie konfederacji Baranowskiego a postuszeństwo oficerom i dyscyplina wojskowa, w: Homo Militans, t. 4: Przysięga wojskowa. Idea i praktyka. Z dziejów wojskowości polskiej i powszechnej, red. A. Niewiński, Oświęcim 2017, s. 80-87 - tam odwołania do dalszej literatury.

69 Regestr dokumentów wystawionych przez kancelarię koronną w 1673 r., AGAD, Metryka Koronna, Sigillata, sygn. 12, k. 84v. Zgodnie z tym dokumentem Boratyński z synem zostali zwolnieni z banicji, nałożonej wcześniej przez Trybunał Lubelski; por. M. Wagner, Stownik biograficzny..., s. 30, hasło: Boratyński Jacek.

70 Zgodnie z klasyfikacją stworzoną przez Marka Wagnera Boratyński kwalifikuje się do grupy oficerów zawodowych, ze względu na służbę wojskową w wymiarze ponad 20 lat. Samego Boratyńskiego Wagner umieszcza jednak w grupie oficerów wykwalifikowanych (służących od 10 do 20 lat), ze względu na sprecyzowanie czasu jego służby jako 1659-1684 (dolna granica nie wiadomo, na jakiej podstawie); zob. idem, Korpus oficerski..., s. $237,238$.

71 Zob. M. Wagner, Baltazar Wilga Godzimirski - ostatni komisarz kozacki Rzeczypospolitej (1692-1699), „Zeszyty Naukowe Uniwersytetu Jagiellońskiego: Prace Historyczne”, 143/2016, z. 2, s. 327-334.
} 
skiego (przed I667 r. Jerzego Sebastiana Lubomirskiego) pełnił jeszcze wcześniej godność porucznika w chorągwi kozackiej (I658-I663)72. Mimo długości służby porucznikowskiej Boratyński nie osiągnął intratnych urzędów i nadań oraz nie awansował też w strukturach wojska. Nie znamy przy tym w szczegółach jego aktywności militarnej, poza w zasadzie udziałem w kampanii wiedeńskiej, po której Boratyński uzyskał ostatni w życiu awans urzędniczy. Wydaje się, że zahamowanie rozwoju kariery Boratyńskiego było związane ze śmiercią podkanclerzego Gnińskiego, który miał o wiele większe możliwości protekcyjne niż jego syn Jan Krzysztof. Pozostając jednak w strefie oddziaływań wojskowego patronatu Jabłonowskiego, powinien mieć możliwości uzyskania protekcji ze strony hetmana. Widocznych jej śladów co prawda nie ma, jednakże w czasie, gdy sprawy organizacyjne armii niemal w całości poczęły zależeć od hetmana Jabłonowskiego (od I683 r.), Boratyński dwukrotnie pełnił ważne funkcje z ramienia wojska - komisarza hibernowego (I683 r.) i posła wojskowego (I695 r.). Widać zatem, że w pewnym stopniu dysponował hetmańskim kredytem zaufania, skoro był delegowany do tych powinności.

Służba wojskowa Boratyńskiego należy do dość ciekawych, rzadko kto bowiem z grona dowódców tego szczebla miał możliwość zapoznać się z bliska z centrum władzy osmańskiej w Stambule, co dokonało się na skutego udziału w poselstwie Gnińskiego. Kolejna kwestia to, że przykład Boratyńskiego, ze względu na fakt zachowania się aktów kapitulacji zawartych z dwoma kolejnymi szefami chorągwi, w której dowodził, jest w zasadzie jedynym punktem odniesienia wobec problemu stwarzania warunków służby przez patronów chorągwi husarskich dla swoich poruczników. Zapewne przykładu tego nie można odnieść do dowódców chorągwi husarskich rangi królewskich i hetmańskich, zajmujących wysokie pozycje w strukturze dowódczej armii koronnej (i w strukturze społecznej oraz urzędniczej), ale już do innych dowódców chorągwi „magnackich” zapewne tak. Wystarczy zwrócić uwagę na Jarosza (Hieronima) Lipińskiego, który tak jak Boratyński został porucznikiem „,pohusarzonej” z pancernej chorągwi kasztelana krakowskiego Stanisława Warszyckiego w drugim kwartale I676 r. Z zachowanego kwitu wiemy, że Lipiński miał taki sam jurgielt dowódcy jak zagwarantowana Boratyńskiemu w kapitulacji suma 4000 zł⒊ Jest zatem wielce prawdopodobne, że Lipińskiemu patron chorągwi stworzył analogiczne warunki służby do tych, które opisał Gniński w kapitulacji zawartej z Boratyńskim. W ten sposób casus podczaszego żydaczowskiego może służyć za studium przypadku w odniesieniu do grupy innych poruczników husarskich o podobnym statusie w wojsku. Sam temat służby wojskowej Boratyńskiego nie został na pewno wyczerpany, a nowe ustalenia może przynieść w tej materii kwerenda w księgach grodzkich i ziemskich z obszaru województwa ruskiego.

\section{Jacek (Hiacynt) Boratyński - Żydaczów Cup-bearer and Hussars' Lieutenant during the Polish-Ottoman Wars in the 2 nd half of the 17 th century. Study of the profession of the soldier - summary Summary}

Through the whole of his military career, Jacek Boratyński served with one formation - winged hussars (husaria). Between I666 and I676 he was a companion (towarzysz) in two hussars'

\footnotetext{
72 Z. Hundert, Aleksander Polanowski..., s. 41-70; idem, Husaria koronna ..., s. 223-224.

73 Kwit J. Lipińskiego na odebranie od S. Warszyckiego pieniędzy na kompanię husarską, Pilica, 2 V 1676, Biblioteka Narodowa w Warszawie, rkps 6649, k. 212; Z. Hundert, Husaria koronna ..., s. 253.
} 
banners (companies): initially in one of Aleksander Michał Lubomirski, voivode of Cracow, then after I668 in the one of Jan Sobieski, grand marshal and grand Crown (Polish) hetman (and since I674 king as Jan III). Then in I676 he became lieutenant in the hussars' banner of Jan Gniński, voivode of Chełmno (since I682 Crown vice-chancellor). In such capacity, as officer of Polish lancers, he took part in Gniński's embassy to Istanbul (I677-I678) and in relief of Vienna in I683. He was part of the group of soldiers that were under patronage of grand Crown hetman Stanisław Jabłonowski. Between I676 and I696 (exact date unknown) Boratyński was one of the commanders in charge of hetman's regiment (pułk) of cavalry. Thanks to military service and patronage, especially from Gniński's side, he received land office ranks - first cup-bearer (cześnik) of Sanok, then deputy cup-bearer (podczaszy) of Żydaczów. His military service is very good benchmark for biographical studies of other Crown officers of the same rank.

Keywords: Jacek Boratyński, the Hussars' Lieutenants; the Polish-Ottoman Wars in the $2^{\text {nd }}$ half of the $17^{\text {th }}$ Century; The Military Patronage; The Crown Winged Hussars

Nota o Autorze: Zbigniew Hundert, ur. w I986 r. w Warszawie, doktor nauk humanistycznych w zakresie historii, adiunkt na WNHiS UKSW w Warszawie. Autor dwóch monografii naukowych (Husaria koronna w wojnie polsko-tureckiej I672-I676, Oświęcim 20I2, II wyd. 20I4; Między buława a tronem. Wojsko koronne w walce stronnictwa malkontentów z ugrupowaniem dworskim w latach I669-I673, Oświęcim 20I4) oraz ponad sześćdziesięciu artykułów, zamieszczonych w czasopismach naukowych, popularnych oraz na witrynach internetowych. Jego zainteresowania badawcze koncentrują się wokół polityczno-wojskowo-ekonomicznych zagadnień dziejów Rzeczypospolitej w drugiej połowie XVII w., z naciskiem na czasy „królów rodaków”. 